\title{
CANOPY GAP CHARACTERISTICS AND TREE REPLACEMENT IN THE SOUTHEASTERN BOREAL FOREST
}

\author{
Daniel D. KNeEshaw AND Yves Bergeron \\ Groupe de recherche en écologie forestière, Université du Québec à Montréal, C.P. 8888, \\ Succursale Centre-Ville, Montréal, Québec, Canada H3C $3 P 8$
}

\begin{abstract}
This study identifies patterns in the gap disturbance regime along a successional gradient in the southern boreal forest and uses this information to investigate canopy composition changes. Gaps were characterized in hardwood, mixed-forest, and conifer stands surrounding Lake Duparquet in northwestern Quebec. From 39 to 80 gaps were evaluated along transects established in each of these stands. The abundance of gap makers and gap fillers and total regeneration was evaluated by species, as well as the size of each gap encountered along the transects. The percentage of the forest in canopy gap was calculated directly from the proportion of the transect in gap and by using gap area and lineintercept techniques. Changes in composition were evaluated from gap-maker and gapfiller distributions and by using transition matrices based on species mortality and regeneration in canopy gaps.

The percentage of the forest in canopy gap ranges from $7.1 \%$ in a 50 -yr-old forest dominated primarily by aspen to $40.4 \%$ in a 234 -yr-old fir-dominated forest. Gap events are due to individual or small-group tree mortality in the early successional forest but become species-specific events controlled by spruce budworm outbreaks in the later stages of succession. Due to the high latitude, direct light only reaches the forest floor in the very largest gaps of the conifer-dominated stands. However, these gaps form slowly as budwormcaused mortality occurs over a number of years, whereas in aspen-dominated stands gaps are formed quickly by the snapping of tree stems. Balsam fir is the most abundant gapfilling species; however, its abundance is negatively correlated to gap size in all stand types. Markovian transition matrices suggest that in the young aspen-dominated forests small gaps lead to species replacment by more shade-tolerant conifers but that in the oldest forests the larger gaps will result in maintenance of the intolerant species and an increase in the abundance of cedar.
\end{abstract}

Key words: balsam fir; boreal forest disturbance regimes; canopy composition; canopy gaps; canopy turnover times; cedar; gap characteristics along a successional gradient; gap size distributions; gap makers and gap fillers; regeneration of trees and forest; spruce budworm-caused gaps; trembling aspen.

\section{INTRODUCTION}

In forests where large-scale disturbances are rare, stand dynamics are controlled by the creation of gaps due to single or multiple overstory-tree mortality. It is within these openings that newly established seedlings or advance regeneration will be recruited to the canopy. Gap dynamics have been described for tropical forests (Whitmore 1978, Brokaw 1985, 1987, Denslow 1987, Lawton and Putz 1988), temperate hardwood forests (Barden 1981, Runkle 1981, 1982, 1990, Runkle and Yetter 1987, Krasny and Whitmore 1992), temperate coniferous forests of western North America (Stewart 1986, Spies et al. 1990), and coniferous montane or subalpine forests (Foster and Reiners 1986, Worral and Harrington 1988, Lertzman and Krebs 1991, Lertzman 1992, Yamamoto 1993, Battles et al. 1995, Battles and Fahey 1996). Although some research has been conducted on boreal forests in Europe (Leemans 1991,

Manuscript received 31 July 1996; revised 23 April 1997; accepted 28 April 1997; final version received 2 June 1997.
Qinghong and Hytteborn 1991, Kuuluvainen 1994), in North American boreal forests the influence of gaps has usually been ignored due to the pervasive nature of large-scale disturbances such as fire (Heinselman 1981, Bergeron 1991, Johnson 1992).

Numerous studies have demonstrated examples of species replacement within different regions of the boreal forest (Carleton and Maycock 1978, Bergeron and Dubuc 1989). Although the replacement of overstory pioneer species by understory trees has thus been acknowledged, it has rarely been studied. In young boreal forest stands, intolerant species such as trembling aspen (Populus tremuloides Michx.) dominate. Over time (after fire) these stands develop into mixed stands as more shade-tolerant conifers replace the pioneers. If succession is allowed to continue the resulting forests will be dominated primarily by these more shade-tolerant conifers. This successional model has been developed from observations of stand chronosequences. Recent work has, however, shown that a second rotation of aspen occurs before stand conversion to conifers (Paré 
and Bergeron 1995), suggesting the importance of gap openings with a light environment sufficient to permit recruitment of the intolerant aspen.

Nonetheless, stand conversion to conifers occurs gradually if the inter-fire period is sufficiently long. With recent research suggesting that the fire return interval is being extended (Bergeron 1991, Johnson 1992, Bergeron and Archambault 1993), an increasingly large proportion of the forest (if not cut) will attain old-growth status. At this stage individual or group tree mortality will dominate and gap-phase processes will be responsible for maintaining the forest canopy (Oliver 1981, Oliver and Larson 1990, Runkle 1991). In the eastern part of the southern boreal forest these mature and old stands are dominated by balsam fir (Abies balsamea (L.) Mill.), a species that is highly vulnerable to spruce budworm outbreaks. The abundance of balsam fir has increased this century due to decreased fire frequency and changes in timber harvesting methods. Retrospective studies suggest that budworm outbreaks are now having a greater impact on the forest than in the earlier part of the century (Blais 1983, Morin et al. 1993).

Research from eastern fir forests suggests that spruce budworm outbreaks lead to a cycling of balsam fir forests (Baskerville 1975, Maclean 1984, 1988), thus maintaining the climax forest. However, in the more species-rich forests of western Quebec and eastern Ontario, Ghent et al. (1957) noted that openings caused by the budworm favored balsam fir in some regions and white spruce (Picea glauca (Moench) A. Voss) in others. In Minnesota, spruce was found to recruit in low but consistent numbers with fir regeneration dependent on the presence of non-host trees and the proportion of overstory fir mortality or gap intensity (Batzer and Popp 1985). However, in none of these cases is the explicit effect of gap size on tree recruitment investigated.

Gap size has not only been positively correlated with resource availability (Canham and Marks 1985), but gradients of gap size have also been proposed as important elements in determining the composition of gap-filling species in tropical forests (Brokaw 1985, 1987, Whitmore 1989). Indeed such theories have been invoked to at least partially explain the maintenance of tropical-forest tree species diversity (Denslow 1987). Gaps of differing size may also explain different successional patterns found with time since fire in boreal forest stands. However, to date the only part of the North American boreal forest gap regime that has been adequately studied is the periodicity of spruce budworm-caused mortality (25-30 yr in our study area [Morin et al. 1993]).

To better understand inter-fire stand dynamics it is important to evaluate gap characteristics as they change from random mortality as trees senesce to budwormcaused mortality. This study therefore attempts to evaluate differences in the gap size-class distribution, as well as mortality and recruitment patterns in gaps in a section of the southern boreal forest. We conducted the study along a chronosequence in an attempt to explain and predict forest compositional change.

\section{STUDY AREA}

Our study was conducted in northwestern Quebec, in the forests surrounding Lake Duparquet, at a latitude between $48^{\circ} 15^{\prime}$ and $48^{\circ} 30^{\prime} \mathrm{N}$ and a longitude of $79^{\circ} 15^{\prime}$ and $79^{\circ} 30^{\prime}$ W. This region, known as Quebec and Ontario's northern clay belt, is characterized by clay deposits from the post-glacial lakes Barlow and Ojibway (Vincent and Hardy 1977). The study region is dominated by a rolling clay lowland interspersed by small rocky hills up to $550 \mathrm{~m}$ in height overlain with reworked till deposits (Bergeron et al. 1983). The climate can be classified as cold and continental, with an annual average temperature of $0.8^{\circ} \mathrm{C}$ and with an average annual precipitation of $857 \mathrm{~mm}$ (Anonymous 1993). The average number of frost-free days is 64 , although frost can occur at any time during the growing season (Anonymous 1993).

Lake Duparquet is located at the southern limit of the boreal forest in the balsam fir-white birch climax region (Thibault and Hotte 1985) or in Rowe's (1972) Missinaibi-Cabonga section where an association of balsam fir, black spruce (Picea mariana (Mill.) BSP.), and white spruce with paper birch (Betula papyrifera Marsh.) and trembling aspen dominates. Jack pine ( $P i$ nus banksiana Lamb.) may also be present on some sites, and, where fire has not occurred for long periods, white cedar (Thuja occidentalis L.) may be abundant (Bergeron and Dubuc 1989).

The fire history of stands in the Lake Duparquet area has been reconstructed using dendroecological techniques (Bergeron 1991, Dansereau and Bergeron 1993). Four of the fire years, 1760, 1847, 1870, and 1916 , representing conifer, mixed-conifer, mixed-hardwood, and hardwood stands, respectively, were retained for use in this study: Gap sampling was also conducted in stands dating from fires in 1944, 1823, and 1797. The fire cycle has changed from an estimated $63 \mathrm{yr}$ for the pre- 1870 period to $>99 \mathrm{yr}$ in the current period. Spruce budworm epidemics have been reconstructed by Morin et al. (1993), with the 1972-1987 outbreak resulting in the death of most of the fir trees (Bergeron et al. 1995). Defoliation due to a 1950's forest tent caterpillar outbreak has also been documented as causing a significant hardwood growth decrease (Bergeron and Charron 1994). Forest harvesting was unimportant until large-scale clearcuts began in the western part of the region in 1978 .

\section{METHODS}

Canopy openness was evaluated along 3-8 transects each located in forests that originated following fires in $1760,1797,1823,1847,1870,1916$, and 1944. References to stand age are to the time since fire as cal- 
TABLE 1. Stand composition in the southern boreal forest surrounding Lake Duparquet, northwestern Quebec, Canada, and characteristics of the different species of canopy trees, by time since the forest last burned. Data are means $\pm 1 \mathrm{SD}$.

\begin{tabular}{cccccc}
\hline $\begin{array}{c}\text { Time } \\
\text { since fire } \\
\text { (yr) }\end{array}$ & Balsam fir & White spruce & Aspen & Birch & Cedar \\
\hline $\begin{array}{llcccc}\text { A) Basal area }\left(\mathrm{m}^{2} / \mathrm{ha}\right) \\
50\end{array}$ & $4.2 \pm 5.1$ & $0.6 \pm 1.6$ & $13.7 \pm 16.1$ & $9.4 \pm 7.0$ & $0.3 \pm 0.8$ \\
78 & $5.9 \pm 4.2$ & $1.7 \pm 3.6$ & $17.3 \pm 15.8$ & $8.4 \pm 6.7$ & $0.8 \pm 1.1$ \\
124 & $7.5 \pm 4.7$ & $4.5 \pm 4.5$ & $14.9 \pm 12.8$ & $7.8 \pm 5.6$ & $0.0 \pm 0.2$ \\
147 & $15.5 \pm 5.5$ & $5.6 \pm 5.4$ & $16.7 \pm 11.8$ & $5.4 \pm 4.2$ & $0.2 \pm 0.6$ \\
171 & $12.8 \pm 5.8$ & $2.4 \pm 3.3$ & $12.1 \pm 11.1$ & $4.7 \pm 3.5$ & $0.4 \pm 0.8$ \\
197 & $10.6 \pm 8.3$ & $2.0 \pm 2.6$ & $0.8 \pm 2.7$ & $9.4 \pm 8.1$ & $0.9 \pm 1.0$ \\
234 & $13.4 \pm 7.4$ & $2.3 \pm 3.3$ & $3.4 \pm 7.3$ & $6.9 \pm 6.6$ & $1.5 \pm 1.3$ \\
B) Density (no. trees/ha) & & & & \\
50 & $514 \pm 520$ & $42 \pm 86$ & $447 \pm 621$ & $874 \pm 598$ & $7 \pm 31$ \\
78 & $746 \pm 527$ & $132 \pm 152$ & $397 \pm 469$ & $683 \pm 492$ & $33 \pm 86$ \\
124 & $730 \pm 434$ & $158 \pm 113$ & $617 \pm 566$ & $295 \pm 180$ & $3 \pm 23$ \\
147 & $2055 \pm 754$ & $148 \pm 129$ & $386 \pm 324$ & $191 \pm 176$ & $32 \pm 117$ \\
161 & $1200 \pm 523$ & $86 \pm 90$ & $399 \pm 516$ & $215 \pm 223$ & $32 \pm 40$ \\
197 & $1266 \pm 725$ & $106 \pm 130$ & $14 \pm 55$ & $360 \pm 395$ & $132 \pm 145$ \\
234 & $1190 \pm 555$ & $66 \pm 76$ & $69 \pm 156$ & $244 \pm 367$ & $338 \pm 352$ \\
\hline
\end{tabular}

culated from fire scars. At each meter along these transects the canopy was evaluated as forest crown (covered) or open (due to the mortality of an adult tree). From 2.5 to $8.4 \mathrm{~km}$ of transects were established in each stand to calculate canopy-gap percentages. Stand composition was evaluated by measuring the basal area and density of trees in 256- $\mathrm{m}^{2}$ quadrats placed at fixed intervals along the transects; it is displayed in Table 1.

In forests that originated following the 1760,1847 , 1870 , and 1916 fires, more detailed sampling of gaps ( $n=80,46,46$, and 39 respectively) along three to five transects was used to evaluate gap size, expanded gap size, species of border trees, tree mortality, and recruitment. Gaps were defined as "the vertical projection of a canopy opening, caused by the mortality of one or more trees, onto the ground" (as verified using a clinometer to ensure vertical sightings), and expanded gaps as "the area circumscribed by the stem of those trees whose crowns define the gap" (Runkle 1982). In the data presented in this paper, expanded gap areas and proportions include gap area. Gap area was evaluated using the formula for an ellipse for small, regularly shaped gaps, and by a modified method of subtending extra width measurements from the central long axis as necessary to capture the form of larger and/or irregularly shaped gaps.

For each of these gaps, the species and number of all bordering trees were noted. The number, species, and relative size class of all dead trees, both standing and fallen, were also recorded. Regeneration was completely censused by species in the smaller gaps $(<100$ $\mathrm{m}^{2}$ ) and was sampled in a two-m-wide band along the gap axes for the larger $\left(>100 \mathrm{~m}^{2}\right)$ gaps. The regeneration was divided into two classes: seedling regeneration and gap fillers. Seedling regeneration was defined as "stems $<1 \mathrm{~m}$ in height," and is an objective evaluation comparable to other regeneration studies. The gap-filler category is an attempt, similar to that of Lertzman (1992), to assess those individuals that due to their height, growth rates and good form will have a better probability of making it to the canopy. Gapfillers were defined as (modified from criteria used for British Columbia Ministry of Forest regeneration and free-to-grow surveys) "seedlings or saplings of good form, $>1 \mathrm{~m}$ in height and $<5 \mathrm{~cm}$ in diameter at breast height, free of competition, and at least $50 \mathrm{~cm}$ from the nearest similar individual of the same species."

The percentage of the forest in canopy opening was calculated following Runkle $(1985,1992)$ as the proportion of the total distance of the transect in canopy opening divided by the length of the transect. For transects where the size of the canopy gap was measured, these calculations can be compared with the gap percentage calculated using the line-intercept method (DeVries 1974 as cited in Runkle 1992), in which

$$
e(X)=\frac{1}{L} \sum_{j=1}^{n} \frac{X_{j}}{d_{j}}
$$

where $e(X)=$ estimate of the proportion of the forest in canopy gap, $L=$ the length of the transect, $X_{j}=$ area of the $j$ th gap, and $d_{j}=$ the diameter of the the $j$ th gap.

This technique can also be modified to calculate the density of gaps per hectare within different size classes as

$$
\text { Density/ha }=10^{4} \times \frac{1}{L} \times \sum_{j=1}^{n} \frac{1}{d_{j}}
$$

for $j=1, \ldots, n$ gaps of a given size class.

Gap size-class distributions and gap diameter to tree height distributions were compared using KolmogorovSmirnov tests. The gap-filler and all other regeneration data for most species could not be normalized using ecologically meaningful transformations and thus re- 
TABLE 2. Gap and expanded gap size characteristics for different-aged boreal forests in northwestern Quebec.

\begin{tabular}{|c|c|c|c|c|c|c|c|}
\hline \multirow{3}{*}{$\begin{array}{c}\text { Forest } \\
\text { age (yr) }\end{array}$} & \multirow[b]{3}{*}{ Forest type } & \multicolumn{3}{|c|}{ Gap area } & \multicolumn{3}{|c|}{ Expanded gap area } \\
\hline & & \multirow{2}{*}{$\begin{array}{l}\text { Total } \\
(\%)\end{array}$} & \multicolumn{2}{|c|}{ Range $\left(\mathrm{m}^{2}\right)$} & \multirow{2}{*}{$\begin{array}{l}\text { Total } \\
(\%)\end{array}$} & \multicolumn{2}{|c|}{ Range $\left(m^{2}\right)$} \\
\hline & & & Min. & Max. & & Min. & Max. \\
\hline 50 & Hardwood & 7.1 & NA & NA & NA & NA & NA \\
\hline 78 & & 11.3 & 4.1 & 214 & 19 & 19.5 & 434 \\
\hline 124 & & 18.7 & 6.3 & 390 & 26.1 & 34.4 & 577 \\
\hline 147 & Mixed & 24.4 & 4.4 & 1200 & 32 & 11.6 & 1450 \\
\hline 171 & & 28.2 & $\mathrm{NA}$ & NA & NA & NA & NA \\
\hline 197 & & 35.3 & NA & NA & & NA & NA \\
\hline 234 & Conifer & 40.9 & 10.2 & 3090 & 53.9 & 35.8 & 3480 \\
\hline
\end{tabular}

Notes: Max. $=$ maximum, $\mathrm{Min} .=$ minimum; $\mathrm{NA}=$ not available.

lationships between advance regeneration and gap size by species and by stand age were tested using a Spearman correlation test.

To evaluate the potential effect of gaps on succession, Markovian transition probabilities were used, with individual gaps as the entity of evaluation rather than individual trees. This approach does not presuppose tree mortality and subsequent tree replacement but bases transitions on currently observed replacement processes. Replacement probabilities were calculated for the youngest hardwood stand, the combined (147and 170-yr) mixed stands (since the distributions of the proportion of forest in gap diameter to canopy height classes were not statistically different, KolmogorovSmirnov test $P>0.05$ ) and the oldest 234-yr-old conifer-dominated stand. It has been demonstrated that stationary Markovian models do not provide accurate predictions throughout succession due to changing transition probabilities (Binkley 1980, Bellefleur 1981). Thus, only one iteration for each model was performed on current composition. Replacement probabilities for each species were calculated based on the proportions, by species, of gap fillers to gap makers in each gap. These individual gap probabilities were then pooled by gap size class. The same procedure was then followed to calculate seedling regeneration to gapmaker proportions. The proportion of forest area in each gap size class was then used to weight the proportions before summing them to get the overall transition probabilities.

Successional change in the tree layer is a function of both compositional changes in gaps and canopy turnover times. These turnover times can be calculated by dividing the time taken to fill a gap $\left(T_{\text {flll }}\right)$ by the proportion of the forest in gap. These calculations were made using the assumption that gaps were filled when gap fillers reach a height of $7 \mathrm{~m}$ and using stem analysis data from the region (Y. Bergeron, unpublished data). These data show that fill times vary with stand age. In the younger forests $T_{\text {fill }}$ approaches $30 \mathrm{yr}$ whereas in the older forests $T_{\text {fill }}$ is $\sim 15 \mathrm{yr}$.

\section{RESULtS}

\section{Gap characteristics}

The percentage of the forest in canopy gap ranged from $7.1 \%$ in the 50 -yr-old stand to $40.4 \%$ in the stand that burned $234 \mathrm{yr}$ ago (Table 2). The proportion of the forest in expanded gap was $8-13 \%$ higher. In relative terms the proportion of forest in expanded gap was greater in the younger forests due to the larger sized crowns of the overstory aspen. The largest gaps were found in the oldest conifer-dominated forests, although gap boundaries for gaps $>1000 \mathrm{~m}^{2}$ in these forests were somewhat arbitrary due to the large size of the gaps and the heterogeneous open nature of these older forests. Residual trees were also occasionally found within the larger gaps.

Gap size distributions show that, in the all but the oldest forest, the majority of gaps are found in the smallest size classes (Fig. 1). In the oldest forest the gaps are more evenly and continuously distributed throughout the size classes. Gap distributions for each of the four studied forests were significantly different (Kolmogorov-Smirnov tests, $P<0.01$ ).

It has often been suggested that simple measures of gap area do not provide an accurate portrayal of the potential impact of various-sized openings because of differences in tree heights between stands within the same study and also between studies. In this study, aspen-dominated stands had much taller canopies than fir-dominated stands, as aspen individuals can easily attain heights of $30 \mathrm{~m}$ while balsam fir canopies may be 6-12 $\mathrm{m}$ lower (Paré and Bergeron 1995). To account for this difference, gap distributions for each differentaged forest are also presented on the basis of the ratio of gap diameter to canopy height (Fig. 2). The gapdiameter-to-canopy-height ratios were not significantly different between the two mid-succession stands (120 and $147 \mathrm{yr}$ old) (Kolmogorov-Smirnov tests, $P>0.05$ ).

The smallest shadow length (i.e., on the summer solstice) for our study area is 1.1224 times the canopy height. This means at this latitude, gap ratios must be greater than this to receive full direct sunlight within 

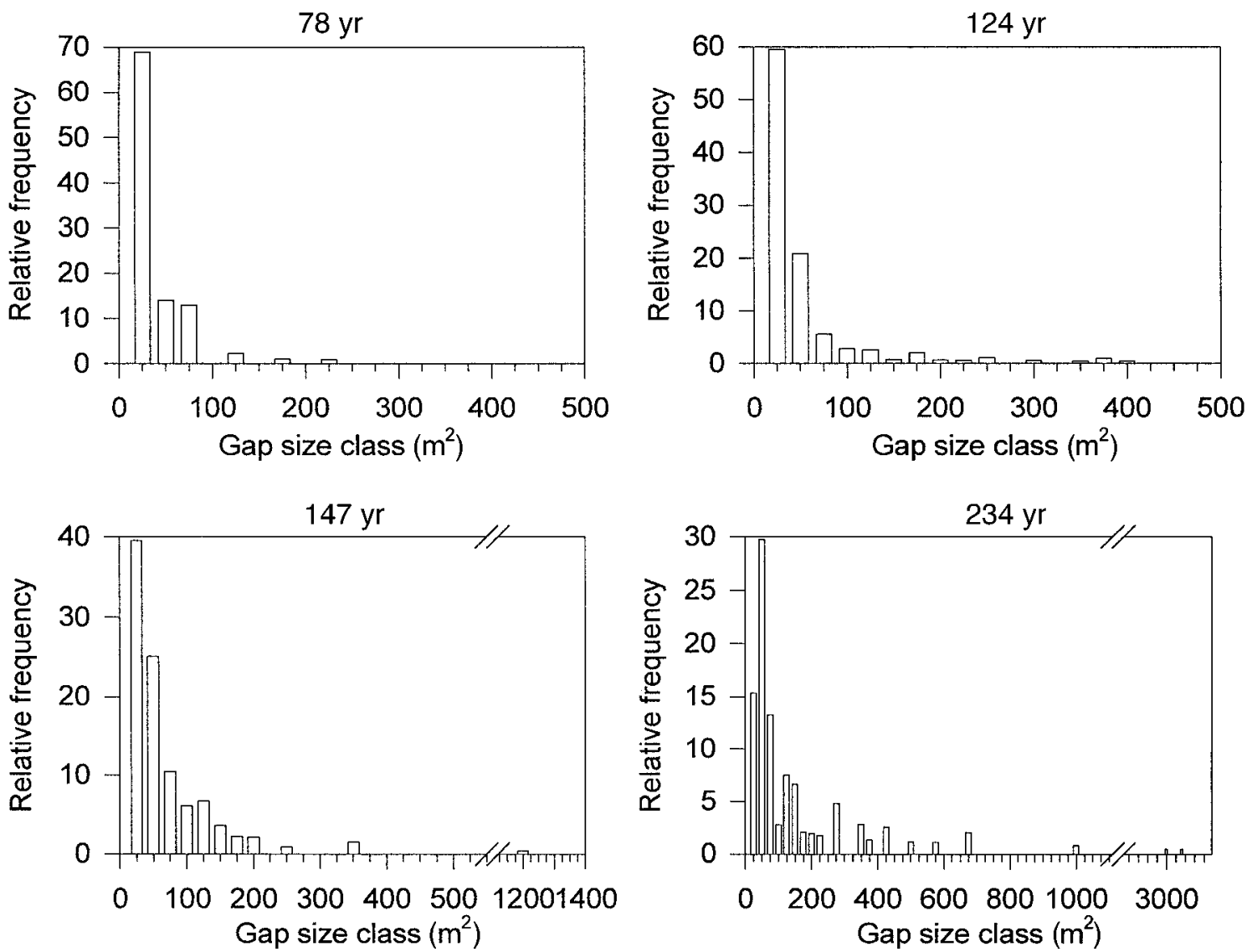

FIG. 1. Relative frequency of gap size distributions for boreal forests that have not burned for 78, 120, 147, and 234 yr. Note different axis scales.

the projected outline of the gap. Thus very few gaps except the largest ones in the old-growth forest receive direct sunlight at the forest floor.

\section{Mortality and recruitment}

In all but the youngest forest, gaps are created primarily by the mortality of balsam fir trees (Fig. 3). Fir trees make up $36 \%$ of the gap makers in the 78 -yr-old forest, increase to $83 \%$ of the gap makers in the midsuccessional, 124-147-yr-old, forests and approach $90 \%$ of the gap makers in the oldest ( 234 yr old) forest. In the 78-yr-old stand, gaps are caused primarily by the death of aspen. As the aspen are generally much larger than the fir trees, it requires a smaller number of deaths to create similar-sized openings. Despite the smaller stature of fir, gaps created by fir mortality attain large sizes due to the severity of the last spruce budworm outbreak. This outbreak effectively killed most overstory fir trees in the area (Bergeron et al. 1995). It is also interesting to note that even in the 76-yr-old aspen-dominated stand, gaps are not due to individual tree deaths but rather are usually the result of multiple gap-maker mortality (Fig. 3).

In all four of the intensively studied stands balsam fir is the most abundant species, both in terms of gap fillers (Fig. 4) and all regeneration combined (not shown). The trend in the number of gap fillers per gap (all species combined) is unusual in that it does not increase with gap size as would be expected. Instead there appears to be a plateau, except perhaps in the youngest stand, that occurs at gap sizes between 150 and $200 \mathrm{~m}^{2}$ and beyond which the total number of gap fillers declines (Fig. 4). In fact, there is a negative correlation between the density of both balsam fir seedlings and balsam fir gap fillers and gap size in all forests (Table 3). Birch and white spruce have positive relationships to gap size in the mixed and conifer-dominated forests.

Gap regeneration (relative to the number of gap makers) was most abundant in the youngest stand (Table 4). Mortality of fir adults exceeds recruitment from gap fillers in all but the youngest stand, suggesting that if gap fillers are a reasonable prediction of the future stand, fir densities will be lower than in the original forest (although fir may still be the most abundant species in the forest), or that recruitment processes are slower in these older forests.

Transition probabilities for the different species sug- 


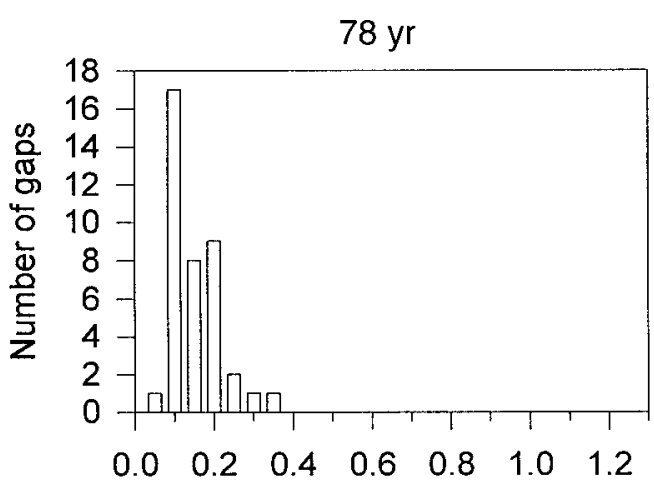

Gap diameter / canopy height

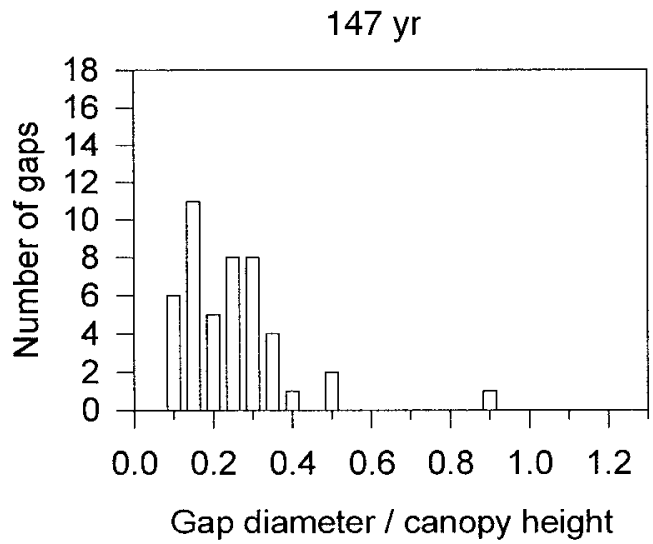

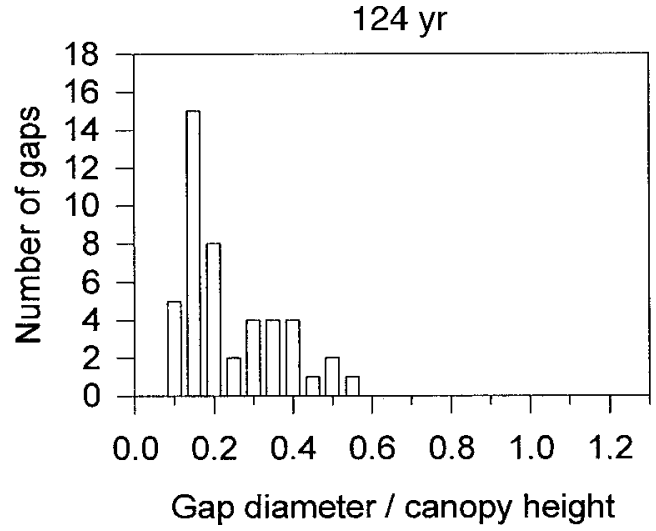

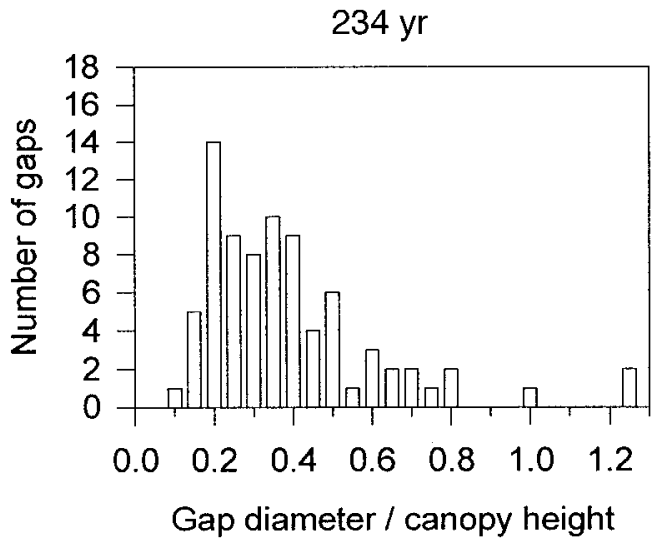

FIG. 2. Gap frequency vs. the ratio of gap diameter to canopy height for four different-aged boreal forests.

gest that fir will be the most successful species in recruiting to the canopy in all stages of forest development, although its greatest abundance occurs in the transition from mixed to old conifer-dominated stands (Table 5). The model based on gap fillers does not, however, show fir to be as successful as the model based on all regeneration. Aspen's lowest projected abundance, based on both the gap filler and regenerationbased models, is in the transition from our oldest stands into an even older state not observed in our study area. Spruce and birch fluctuate between models but seem to maintain themselves as important secondary components of the forest. Cedar's relative abundance, on the other hand, increases as a result of recruitment in the 234-yr-old forest.

As a result of the increase in gap area, canopy turnover time decreases with stand age (Fig. 5). The time to reach $7 \mathrm{~m}$ in height (the fill time), derived from stem analysis data, also decreases in the older forests, leading to even larger changes in turnover time with stand age. Thus the rate of transition from one state to another (as estimated by transition probabilities) accelerates from the youngest towards the oldest stands. The concept of a static turnover time is therefore highly unrealistic, especially in the early stages of succession where it decreases rapidly.

\section{DISCUSSION}

\section{Gap characteristics}

The picture that emerges from our study is of small, randomly generated gaps in the initial stage of forest succession (dominated by the intolerant hardwoods, primarily aspen). The percentage of the 78-yr-old forest in gaps (11\%, Table 2) compares well to those reported for temperate hardwood forests to the south (Runkle 1982, 1985, Krasny and Whitmore 1992).

With an increase in balsam fir abundance, spruce budworm-mediated gaps dominate the landscape, and both the percentage of forest in gap and the average gap size increase dramatically. However, the percentage of our mixed-wood forest in canopy gaps (18.7-24.4\%) falls nearly within the range (3.2-24.2 $\%$ ) reported by Runkle (1982) and within the 5-31\% suggested by Yamamoto (1992) for temperate forests. Gap area in our coniferous forests is also comparable to other conifereous forests in which gap area varied from 15 to $63 \%$ but on general averaged $30-40 \%$ of the total area (Worrall and Harrington 1988, Spies et al. 1990, Lertzman and Krebs 1991, Qinghong and Hytteborn 1991, Perkins et al. 1992, Battles and Fahey 1996).

In our study the small range of gap sizes (Fig. 1) in 

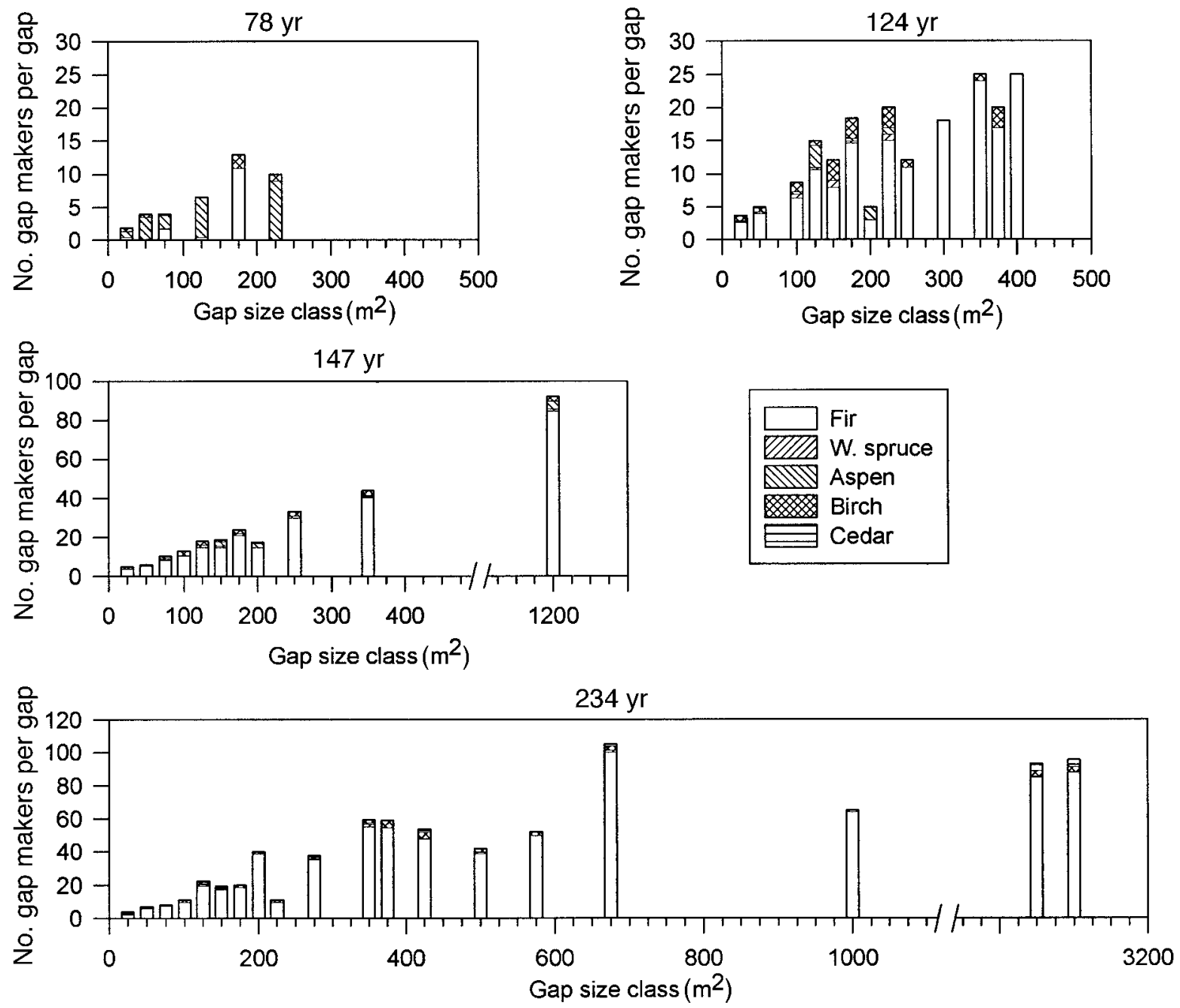

FIG. 3. The number of gap makers of each species per gap as found in each gap size class.

the hardwood forest is due to the random nature of gap events throughout the forest as individual or groups of overstory trees senesce and die. The greater range of gap sizes in the older conifer forests at Lake Duparquet is due to the the mortality of all individuals in differentsized patches of fir due to outbreaks of the spruce budworm. Large gap events are usually caused by exogenous factors (Kuuluvainen 1994). While spruce budworm is the causal agent in fir-dominated regions of eastern North America, severe wind storms have been cited as the source of large gaps in other coniferous forests (Qinghong and Hytteborn 1991).

Despite the large size of these openings, direct light only reaches ground level in the very largest gaps (Fig. 2) due to the low sun angle at these northern latitudes. As shown by Canham et al. (1990), increases in light at ground level will be displaced to the north of the gap edge. The deep crowns of the three conifer species and the abundance of mountain maple (Acer spicatum) in hardwood stands and in large gaps will effectively reduce the amount of direct light penetration into the understory north of the gaps. Seedlings growing in the area north of the gaps will also experience declining light levels as they grow in height, whereas seedlings located within gaps will grow into a zone of higher light levels. In the boreal forests of northeastern China, Ban et al. (in press) found that increased light levels in obliquely projected gaps (e.g., to the north of the gap) resulted in increased seedling survival but that vertically projected gaps were necessary for seedling recruitment to the canopy. Gap expansion to the north of the original gap area may therefore be an important element in gap-filler recruitment to the canopy in hardwood and mixed forests. In our conifer forests, gap formation is essentially a periodic phenomenon due to spruce budwormcaused mortality $(90 \%$ of mortality in the oldest stands is composed of fir). Gap expansion may, therefore, account for only a small proportion of the area in gaps in these old forests. 

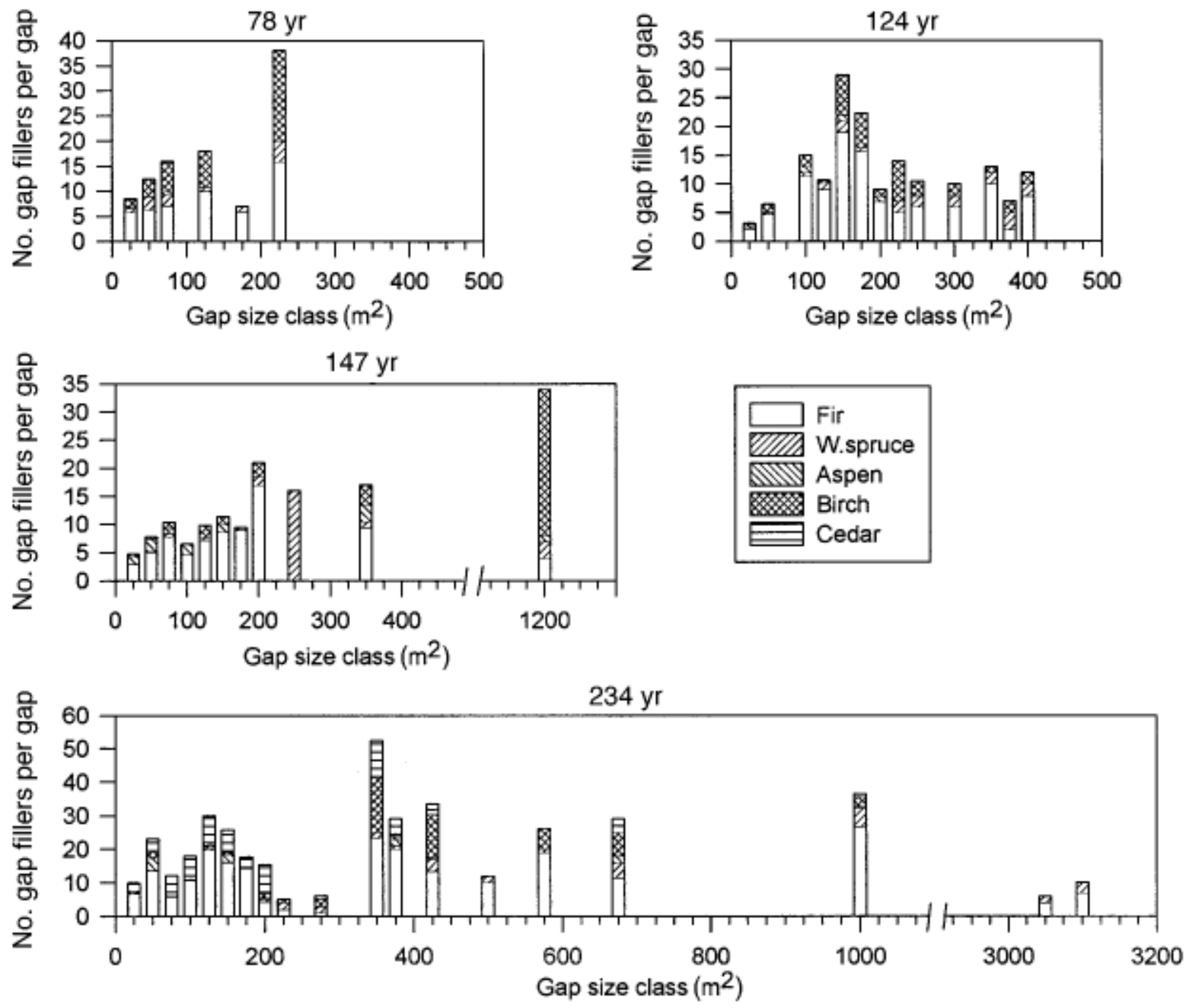

FIG. 4. The number of gap fillers by species found in each gap size class.

TABLE 3. Spearman correlation, $r_{\mathrm{g}}$, between gap fillers and seedling abundance by species, and gap size for three forest age classes. NS $=$ not significant at $P>0.05$.

\begin{tabular}{|c|c|c|c|c|c|c|}
\hline \multirow[b]{3}{*}{ Species } & \multicolumn{6}{|c|}{ Correlation with gap size } \\
\hline & \multicolumn{2}{|c|}{$\begin{array}{l}78 \text {-yr-old } \\
\text { stand }\end{array}$} & \multicolumn{2}{|c|}{$\begin{array}{l}124 \text { and } 147 \text { yr old, } \\
\text { combined }\end{array}$} & \multicolumn{2}{|c|}{$\begin{array}{l}\text { 234-yr-old } \\
\text { stand }\end{array}$} \\
\hline & $r_{\mathrm{s}}$ & $P$ & $r_{\mathrm{s}}$ & $P$ & $r_{\mathrm{s}}$ & $P$ \\
\hline \multicolumn{7}{|c|}{ Gap-filler species } \\
\hline $\begin{array}{l}\text { Fir } \\
\text { Spruce }\end{array}$ & -0.581 & 0.001 & -0.505 & 0.0001 & $\begin{array}{r}-0.453 \\
0.405\end{array}$ & $\begin{array}{l}0.0001 \\
0.0002\end{array}$ \\
\hline $\begin{array}{l}\text { Spruce } \\
\text { Aspen }\end{array}$ & \multicolumn{2}{|c|}{ NS } & \multicolumn{2}{|c|}{ NS } & \multicolumn{2}{|c|}{0.405 NS } \\
\hline Birch & \multicolumn{2}{|c|}{$\begin{array}{l}\text { NS } \\
\text { NS }\end{array}$} & 0.237 & 0.0349 & 0.400 & 0.0002 \\
\hline Cedar & \multicolumn{2}{|c|}{ NS } & \multicolumn{2}{|c|}{ NS } & -0.250 & 0.0300 \\
\hline \multicolumn{7}{|c|}{ Seedling species } \\
\hline Fir & -0.383 & 0.0160 & -0.260 & 0.0207 & \multicolumn{2}{|c|}{ NS } \\
\hline Spruce & \multicolumn{2}{|c|}{ NS } & -0.266 & 0.0690 & 0.350 & 0.0014 \\
\hline Aspen & \multirow{2}{*}{\multicolumn{2}{|c|}{$\begin{array}{l}\text { NS } \\
\text { NS }\end{array}$}} & \multicolumn{2}{|c|}{ NS } & 0.220 & 0.0446 \\
\hline Birch & & & \multicolumn{2}{|c|}{ NS } & 0.374 & 0.0006 \\
\hline Cedar & \multicolumn{2}{|c|}{ NS } & & & \multicolumn{2}{|c|}{ NS } \\
\hline
\end{tabular}


TABLE 4. Ratio of the number of gap fillers and seedlings to the number of gap makers, by forest type.

\begin{tabular}{lcccccc}
\hline \hline \multirow{2}{*}{$\begin{array}{l}\text { A) Gap fillers } \\
\text { Forest age }\end{array}$} & \multicolumn{7}{c}{ Ratio of the no. of gap fillers to: } \\
\cline { 2 - 7 } \multicolumn{1}{c}{$(\mathrm{yr})$} & Fir & White spruce & Aspen & Birch & Cedar & Total \\
\hline 78 & 3.3 & 126.8 & 0.1 & 1.3 & 3.5 & 1.9 \\
124 and 147 & 0.5 & 5.3 & 1.3 & 0.7 & 1.4 & 0.6 \\
234 & 0.6 & 1.7 & 18 & 3.2 & 1.4 & 0.8
\end{tabular}

B) Seedlings

Forest age Ratio of the no. of seedlings to:

\begin{tabular}{|c|c|c|c|c|c|c|}
\hline $\begin{array}{c}\text { rest a } \\
(\mathrm{yr})\end{array}$ & $\overline{\text { Fir }}$ & White spruce & Aspen & Birch & Cedar & Total \\
\hline $\begin{array}{l}78 \\
124 \text { and } 147 \\
234\end{array}$ & $\begin{array}{r}18.3 \\
6.5 \\
7.4\end{array}$ & $\begin{array}{r}651.6 \\
39.7 \\
10.5\end{array}$ & $\begin{array}{r}2.1 \\
5.1 \\
18.3\end{array}$ & $\begin{array}{r}1.4 \\
8.5 \\
10.7\end{array}$ & $\begin{array}{r}9.4 \\
863.2 \\
17.7\end{array}$ & $\begin{array}{l}9.1 \\
7.5 \\
8.3\end{array}$ \\
\hline
\end{tabular}

\section{Mortality and recruitment}

There is a definite progression in the species of gap maker with time since fire that parallels the shade tolerance of the species in these forests. However, despite the greater number of fir gap makers in the 123-yr-old stand, hardwood mortality continues to be important due to the greater size of adult birch and aspen compared to fir The expanded-gap measures are proportionately much greater under the large-crowned aspen canopies than under the narrow, conical, fir canopies. Such a difference implies that the death of a single aspen adult will have a greater effect on gap size than that of a fir. Similarly, the rate of gap formation, which influences the rate at which resources become available, varies between the aspen- and fir-dominated forests. Aspen death was almost always the result of a snapped bole (the usual mode of death) or uprooting. Balsam fir on the other hand, usually died standing due to defoliation by the spruce budworm. Seven years after the end of the last epidemic and twelve years after the mortality of many of the adults (Bergeron et al. 1995 ), $>80 \%$ of the boles are still standing (although

TABle 5. Percentage future composition of boreal forests based on transition probabilities from tree mortality and gap fillers, and regeneration in forests of different ages.

\begin{tabular}{lccc}
\hline \hline & $\begin{array}{c}\text { 78-yr-old } \\
\text { aspen } \\
\text { forest }\end{array}$ & $\begin{array}{c}\text { 124-147 } \\
\text { yr-old } \\
\text { mixed } \\
\text { forest }\end{array}$ & $\begin{array}{c}\text { 234-yr-old } \\
\text { conifer } \\
\text { forest }\end{array}$ \\
\hline A) Gap filler & & & \\
Balsam fir & 61.5 & 72.7 & 54.0 \\
White spruce & 14.8 & 9.9 & 8.0 \\
Trembling aspen & 4.9 & 7.2 & 3.5 \\
Paper birch & 16.5 & 9.8 & 8.5 \\
Eastem white cedar & 2.3 & 0.4 & 26.0 \\
B) Regeneration & & & \\
Balsam fir & 71.0 & 78.5 & 68.1 \\
White spruce & 11.1 & 6.2 & 2.0 \\
Trembling aspen & 12.8 & 5.8 & 6.1 \\
Paper birch & 4.5 & 8.7 & 6.3 \\
Eastern white cedar & 0.6 & 0.8 & 17.6 \\
\hline
\end{tabular}

the branches have long since fallen). Thus gaps in conifer-dominated stands are slowly created over a period of years, whereas hardwood gaps are usually sudden events. Gradual gaps have also been noted as being important in forests where diseases, notably beech-bark disease, are a major cause of overstory mortality (Krasny and Whitmore 1992).

The high number of gap makers per gap observed in this study exceeds those reported for all other studies, in which the number of gap makers rarely exceeds 20 (Spies et al. 1990, Lertzman and Krebs 1991, Qinghong and Hytteborn 1991). This is natural, considering that the agent of death-thepruce budworm-causes

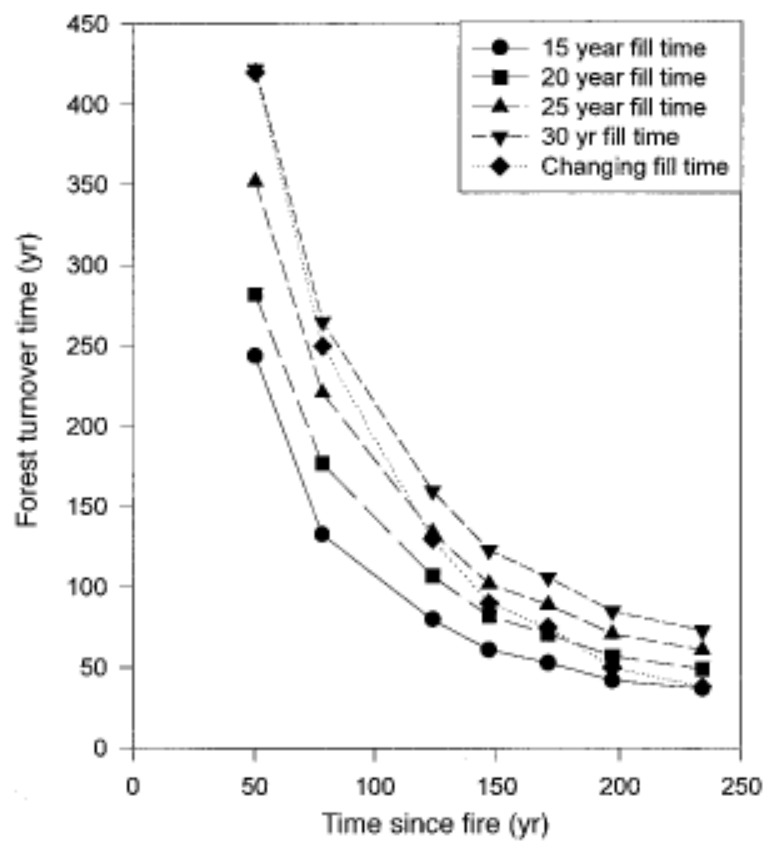

FIG. 5. Changes in canopy turnover time with time since fire for various gap-fill times (gap-fill time is the time taken for the regeneration in a gap to close the gap opening). The changing fill time is the best estimate of the actual fill times for forests that initiated at different times following fire. 
large patches of mortality in epidemic years. However, even the youngest hardwood stand in our study is dominated by multiple gap-maker gaps. This may be a reflection of the stand age ( $78 \mathrm{yr}$ ), which is close to the average lifespan of aspen in the area. For stands of this age and older, synchronous mortality may become more and more frequent. We also speculate that such group death may be linked to the clonal establishment of aspen.

The fact that balsam fir is the most abundant gap filler and seedling species in these forests is not surprising due to its prolific seeding and its status as a late-successional species. However, the fact that the numbers of seedlings does not increase with gap size is. Kneeshaw and Bergeron (1996) suggest that in these large canopy gaps there is a trade-off between increased resource availability and increased competition from shrubby species. Such competition may be responsible for the fact that the number of gap fillers is not at this present time sufficient to replace the number of gap makers (Table 4A). This reduced or delayed recruitment may also lead to an increase in canopy turnover times. Earlier studies from western Quebec, eastern Ontario, and Minnesota all note that competition from shrub species such as hazel (Corylus cornuta), raspberry (Rubus idaeus), and mountain maple (Acer spicatum) is greatest when overstory mortality is high (Ghent et al. 1957, Batzer and Popp 1985). Personal observations for our study area suggest that raspberry is an unimportant competitor in these forests and that the strongest competition comes from mountain maple, followed by hazel.

Balsam fir's projected dominance in filling gaps in the 78-yr-old forest is primarily a reflection of its high stem density. The composition of existing 147- and 161-yr-old forests shows that fir is indeed the most abundant species (Table 1B). However, in terms of basal area these forests are not yet dominated by balsam fir (Table 1A). Earlier research from our study area showed a slow progression towards mixed stands due to a second generation of aspen (Paré and Bergeron 1995; Y. Bergeron, unpublished data). Aspen's more rapid growth and its greater height at maturity result in two-tiered stands, dominated by aspen with a subcanopy of shorter balsam fir (Paré and Bergeron 1995).

The second set of probabilities, derived from the mid-aged forests, predicts that succession in these gaps will lead to a more heavily conifer-dominated forest. This prediction agrees with similar observations from chronosequences in the area, in which the oldest stands are dominated primarily by conifers, in particular by balsam fir (Table 1). Transitions from spruce budwormcaused gaps in the oldest forests to the hypothetical next generation do not suggest the continued maintenance of the current canopy composition. Rather, the importance of fir decreases in these large gaps. This contrasts with work from pure fir forests in eastern Canada in which it has been suggested that spruce bud- worm-created openings would lead to a maintained cycling of fir forests (Baskerville 1975, Maclean 1984, Morin and Laprise 1989, Morin 1994).

Hardwood species are maintained via gap recruitment but they do not increase in abundance. Although large gaps would at first seem suitable to the recruitment of fast-growing shade-intolerant species, the nature of gap creation by the spruce budworm does not result in an immediate increase in resources. Instead, trees die slowly over a number of years, with maximum mortality usually occurring 6-7 yr after the onset of an outbreak (Baskerville and MacLean 1979). These large, slow-forming gaps are generally dominated by shrubs.

The tree species that is projected to increase the most in the generation following our oldest stand (i.e., in the last transition series) is eastern white cedar. Considering the long life-span of species such as cedar (and white spruce), which live 3-4 or more times longer than fir (Burns and Honkala 1990), the actual increase in abundance may be greater than suggested by the transition models. Cedar is considered to be extremely shade tolerant, poorly adapted to fire, and a non-host tree for the budworm. It has also been suggested that the presence of decomposing logs (as seedbeds) may be necessary before this species can become abundant. An evaluation of cedar regeneration in the area demonstrates a large increase in the oldest present-day stands (Kneeshaw and Bergeron 1996). Frelich and Reich (1995), on the basis of their transition probabilities, suggest that spruce budworm outbreaks will limit fir's ability to increase in dominance but find no similar constraint for cedar in the absence of fire. Paleoecological reconstructions also suggest that cedar was most abundant when fire cycles were thought to be longest (Liu 1990, Richard 1993). The projected increase in cedar does not seem therefore to be related to large budworm-caused gaps but rather to the length of time since fire.

In conclusion, small gaps found early in succession in these boreal forests generally promote a gradual transition towards a more fir-dominated forest. As the forest becomes increasingly dominated by fir, gap dynamics are controlled more and more by outbreaks of the spruce budworm. The resulting gaps are aggregated in fir-dominated patches. These larger gaps not only allow for the maintenance of intolerant hardwoods but also promote competition between tree regeneration and shrubby species and may eventually lead to an increase in the proportion of cedar. Our results show that these stands have not entered a state of relative compositional equilibrium, and therefore do not follow the cyclical model of continued fir maintenance after spruce budworm outbreaks that has been proposed for eastern fir forests.

ACKNOWLEDGMENTS

The National Science and Engineering Research Council, Fonds FCAR, and the Minstère des ressources naturelles du 
Québec contributed to the funding for this project. Christian Bedard, Isabelle Aubin, and Robin Duscheneau were indispensable participants in the field work. We would also like to thank Phil Burton and Alain Leduc for their help and Charlie Canham, Jacques Brisson, Christian Messier, and two anonymous reviewers for their comments and suggestions on the manuscript.

\section{Literature Cited}

Anonymous. 1993. Canadian climate normals 1961-1990. Canadian climate program. Environment Canada, Atmospheric Environment Service, Downsview, Ontario, Canada.

Ban, Y., H. Xu, and Y. Bergeron. In press. Gap characteristics and larch regeneration in old-growth Larix gmelini boreal forests of northeastern China. Journal of Vegetation Science.

Barden, L. S. 1981. Forest development in canopy gaps of a diverse hardwood forest in the southern Appalachians. Oikos 37:205-209.

Baskerville, G. L. 1975. Spruce budworm: super silviculturist. Forestry Chronicle 51:138-140.

Baskerville, G. L., and D. A. MacLean. 1979. Budwormcaused mortality and 20-year recovery in immature balsam fir stands. Information Report M-X-102. Canadian Forest Service, Maritime Forest Research Centre, Fredericton, New Brunswick, Canada.

Battles, J. J., and T. J. Fahey. 1996. Spruce decline as a disturbance event in the subalpine forests of the northeastern United States. Canadian Journal of Forest Research 26:408-421.

Battles, J. J., T. J. Fahey, and E. M. B. Harney. 1995. Spatial patterning in the canopy gap regime of a sub-alpine AbiesPicea forest in the northeastern United States. Journal of Vegetation Science 6:807-814.

Batzer, H. O., and M. P. Popp. 1985. Forest succession following a spruce budworm outbreak in Minnesota. Forestry Chronicle 61:75-80.

Bellefleur, P. 1981. Markov models of forest-type secondary succession in coastal British Columbia. Canadian Journal of Forest Research 11:18-29.

Bergeron, Y. 1991. The influence of island and mainland landscapes on boreal forest fire regimes. Ecology 72:19801992.

Bergeron, Y., and S. Archambault. 1993. Decreasing frequency of forest fires in the southern boreal zone of Quebec and its relation to global warming since the end of the 'Little Ice Age'. The Holocene 3:225-259.

Bergeron, Y., A. Bouchard, P. Gangloff, and C. Camiré. 1983. La classification écologique des milieux forestiers de la partie ouest des cantons d'Hebécourt et de Roquemare, Abitibi, Québec. Études écologiques number 9. University of Laval, Quebec City, Quebec, Canada.

Bergeron, Y., and D. Charron. 1994. Postfire stand dynamics in the southern boreal forest (Québec): a dendroecological approach. Ecoscience 1:173-184.

Bergeron, Y., and M. Dubuc. 1989. Succession in the southern part of the Canadian boreal forest. Vegetatio 79:51-63.

Bergeron, Y., A. Leduc, H. Morin, and C. Joyal. 1995. Balsam fir mortality following the last spruce budworm outbreak in northwestern Quebec. Canadian Journal of Forest Research 25:1375-1384.

Binkley, C. S. 1980. Is succession in hardwood forests a stationary Markov process? Forest Science 26:566-570.

Blais, J. R. 1983. Trends in the frequency, extent and severity of spruce budworm outbreaks in eastern Canada. Canadian Journal of Forest Research 13:539-547.

Brokaw, N. V. L. 1985. Gap-phase regeneration in a tropical forest. Ecology 66:682-687.

1987. Gap-phase regeneration of three pioneer tree species in a tropical forest. Journal of Ecology 75:9-19.
Burns, R. H., and B. H. Honkala. 1990. B. H. Silvics of North America. Volume I. Conifers. USDA Forest Service Agricultural Handbook 654.

Canham, C., J. S. Denslow, W. J. Platt, J. R. Runkle, T. A. Spies, and P. S. White. 1990. Light regimes beneath closed canopies and tree-fall gaps in temperate and tropical forests. Canadian Journal of Forest Research 20:620-631.

Canham, C. D., and P. L. Marks. 1985. The response of woody plants to disturbance: patterns of establishment and growth. Pages 197-216 in The ecology of disturbance and patch dynamics. S. T. A. Pickett and P. S. White, editors. Academic Press, New York, New York, USA.

Carleton, T., and P. J. Maycock. 1978. Dynamics of the boreal forest south of James Bay. Canadian Journal of Botany 56: $1157-1173$.

Dansereau, P., and Y. Bergeron. 1993. Fire history in the southern part of the boreal forest of northwestern Quebec. Canadian Journal of Forest Research 23:25-32.

Denslow, J. S. 1987. Tropical rain forest gaps and tree species diversity. Pages 307-323 in The ecology of natural disturbance and patch dynamics. S. T. A. Pickett and P. S. White, editors. Academic Press, New York, New York, USA.

Foster, J. R., and W. A. Reiners. 1986. Size distribution and expansion of canopy gaps in a northern Appalachian spruce-fir forest. Vegetatio 68:109-114.

Frelich, L. E., and P. B. Reich. 1995. Spatial patterns and succession in a Minnesota southern-boreal forest. Ecological Monographs 65:325-346.

Ghent, A. W., D. A. Fraser, and J. B. Thomas. 1957. Studies of regeneration in forest stands devastated by the spruce budworm. Forest Science 3:184-208.

Heinselman, M. L. 1981. Fire and succession in the conifer forests of northern North America. Pages 374-406 in D. C. West, H. H. Shugart, and D. B. Botkin, editors. Forest succession: concepts and application. Springer-Verlag, New York, New York, USA.

Johnson, E. A. 1992. Fire and vegetation dynamics-Studies from the North American Boreal Forest. Cambridge Studies in Ecology. Cambridge University Press, Cambridge, UK.

Kneeshaw, D. D., and Y. Bergeron. 1996. Ecological factors affecting the abundance of advance regeneration in Quebec's southwestern boreal forest. Canadian Journal of Forest Research 26:888-898.

Krasny, M. E., and M. C. Whitmore. 1992. Gradual and sudden forest canopy gaps in Alleghany northern hardwood forests. Canadian Journal of Forest Research 22:139-143.

Kuuluvainen, T. 1994. Gap disturbance, ground microtopography, and the regeneration dynamics of boreal coniferous forests in Finland: a review. Annals Zoology Fenncici 31:35-51.

Lawton, R. O., and F. E. Putz. 1988. Natural disturbance and gap formation in a wind-exposed tropical cloud forest. Ecology 69:764-777.

Leemans, R. 1991. Canopy gaps and establishment patterns of spruce (Picea abies (L.) Karst.) in two old-growth coniferous forests in central Sweden. Vegetatio 93:157-165.

Lertzman, K. 1992. Patterns of gap-phase replacement in a sub-alpine, old-growth forest. Ecology 73:657-669.

Lertzman, K. P., and C. J. Krebs. 1991. Gap-phase structure of a sub-alpine old-growth forest. Canadian Journal of Forest Research 22:1730-1741.

Liu, K. B. 1990. Holocene paleoecology of the boreal forest and Great Lakes-St. Lawrence forest in northern Ontario. Ecological Monographs 60:179-212.

MacLean, D. A. 1984. Effects of spruce budworm outbreaks on the productivity and stability of balsam fir forests. Forestry Chronicle 60:273-279.

1988. Effects of spruce budworm outbreaks on vegetation, structure and succession of balsam fir forests on 
Cape Breton Island, Canada. Pages 253-261 in M. J. A. Werger, P. J. M. van der Aart, H. J. During, and J. T. A. Verhoeven, editors. Plant form and vegetation structure. Academic Publishing, The Hague, Netherlands.

Morin, H. 1994. Dynamics of balsam fir forests in relation to spruce budworm outbreaks in the boreal zone, Québec. Canadian Journal of Forest Research 24:730-741.

Morin, H., and D. Laprise. 1989. Analyse dendroécologique d'une sapinière issue d'un chablis dans la zone boréale, Québec. Canadian Journal of Forest Research 20:17531758.

Morin, H., D. Laprise, and Y. Bergeron. 1993. Chronology of spruce budworm outbreaks near Lake Duparquet, Abitibi region, Quebec. Canadian Journal of Forest Research 23 $1497-1506$.

Oliver, C. D. 1981. Forest development in North America following major disturbances. Forest Ecology and Management 3:153-168.

Oliver, C. D., and B. C. Larson 1990. Forest stand dynamics. McGraw-Hill, New York, New York, USA.

Paré, D., and Y. Bergeron. 1995. Above-ground biomass accumulation along a 230-year chronosequence in the southern portion of the Canadian boreal forest. Journal of Ecology 83:1001-1007.

Perkins, T. D., R. M. Klein, G. J. Badger, and M. J. Easter 1992. Spruce-fir decline and gap dynamics on Camels Hump, Vermont. Canadian Journal of Forest Research 22: 413-422.

Qinghong, L., and H. Hytteborn. 1991. Gap structure, disturbance and regeneration in a primeval Picea abies forest. Journal of Vegetation Science 2:391-402.

Richard, P. J. H. 1993. Origine et dynamique postglaciaire de la forêt mixte au Québec. Review of Palaeobotany and Palynology 79:31-68.

Rowe, J. S. 1972. Forest regions of Canada. Environment Canada, Ottawa, Ontario, Canada.

Runkle, J. R. 1981. Gap regeneration in some old-growth forests of the eastern United States. Ecology 62:10411051 .

1982. Patterns of disturbance in some old-growth mesic forests of eastern North America. Ecology 63:15331546.

1985. Disturbance regimes in temperate forests.
Pages 17-33 in The ecology of natural disturbance and patch dynamics. S. T. A. Pickett and P. S. White, editors. Academic Press, New York, New York, USA.

. 1990. Gap dynamics in an Ohio Acer-Fagus forest and speculations on the geography of disturbance. Canadian Journal of Forest Research 20:632-641.

. 1991. Gap dynamics of old-growth eastern forests: management implications. Natural Areas Journal 11:1925

1992. Guidelines and sample protocol for sampling forest gaps. USDA Forest Service Pacific NorthWest Research Station General Technical Report PNW-GTR-283.

Runkle, J. R., and T. C. Yetter. 1987. Treefalls revisited: gap dynamics in the southern Appalachians. Ecology 68:417424.

Spies, T., J. F. Franklin, and M. Klopsch. 1990. Canopy gaps in Douglas-fir forests of the Cascade mountains. Canadian Journal of Forest Research 20:534-544.

Stewart, G. H. 1986. Population dynamics of a montane conifer forest, western Cascade Range, Oregon, USA. Ecology 67:534-544.

Thibault, M., and D. Hotte. 1985. Les régions écologiques du Québec mériodional (Map 2nd approximation). Ministère de l'Energie et des Ressources du Québec, Direction de la recherche et du développement, Quebec City, Quebec, Canada.

Vincent, J. S., and L. Hardy. 1977. L'évolution et l'extinction des grands lacs glaciares Barlow et Ojibway en territoire québeç ois. Gegraphie Physique et Quaternaire 31:357372.

Whitmore, T. C. 1978. Gaps in the forest canopy. Pages 639655 in P. B. Tomlinson and M. H. Zimmerman, editors. Tropical trees as living systems. Cambridge University Press, New York, New York, USA.

- 1989. Canopy gaps and the two major groups of forest trees. Ecology 70:536-538.

Worrall, J. J., and T. C. Harrington. 1988. Etiology of canopy gaps in spruce-fir forests at Crawford Notch, New Hampshire. Canadian Journal of Forest Research 18:1463-1469.

Yamamoto, S. I. 1992. The gap theory in forest dynamics. Botanical Magazine of Tokyo 105:375-383.

. 1993. Gap characteristics and gap regeneration in a subalpine forest on Mt. Ontake, central Honshu, Japan. Ecological Research 8:277-285. 